\title{
SELECTION OF OPTIMAL DESIGN PARAMETERS FOR EPOXY/E-GLASS COMPOSITE USING TAGUCHI BASED GREY THEORY
}

\author{
RAMAR M. ${ }^{1}$, SAKTHI SUBA RAJA S. ${ }^{2}$ \\ 1Department of Mechanical Engineering, Government College of Engineering, Tirunelveli, Tamilnadu, India \\ 2Department of Mechanical Engineering, Einstein College of Engineering, Tirunelveli, Tamilnadu, India \\ Email: 1ramarlacks400@gmail.com
}

\begin{abstract}
The design parameters and manufacturing technologies involved in the fabrication of composites is a vital advance in the development of materials. The selection of design parameters like matrix material, fillers, volume fraction, curing temperature and treatment play an important role in bringing tailor made properties in the resulting composites. The present work focusses on identifying the proper design parameters for Epoxy/E-Glass composite to enhance its strength. The fabrication trials are based on Taguchi's $L_{9}$ orthogonal array. Impact strength and tensile strength of the composites are observed for various combinations of design parameters. Grey relational analysis (GRA) properly supplemented by the analysis of variance (ANOVA) is employed to predict the optimal design parameters.
\end{abstract}

Key words: Taguchi; Epoxy/E-Glass composites; Grey relational analysis; ANOVA; Orthogonal array; Optimization.

\section{INTRODUCTION}

The epoxy matrix composites find wide applications as automotive interiors and packing containers. The Eglass reinforced epoxy composites have good tolerance to wear and temperature [1]. The durability of these materials combined with their easy processing characteristics enhance their engineering applications. The selection of design parameters like the material of the matrix, filler material, volume of filler, curing temperature and fibre treatment play a vital role in ensuring the tailor made properties in the resulting composites [2]. The techniques used to identify the optimal parameter design includes the genetic algorithm (GA), technique for order of preference by similarity to ideal solution (TOPSIS), grey relational analysis (GRA), principal component analysis (PCA), simulated annealing (SA), response surface methodology (RSM), desirability analysis and fuzzy logic $[3,4,5]$.

The Taguchi technique is found to be effective in optimization of single response. Though the method has its limitation while handling the multiple responses, the strength of the technique lies in its power to predict the near optimal solutions with a lesser number of experimental trials $[6,7,8]$. The grey theory based RSM is observed to predict the optimal operating condition in different scenario. The method involves the generation of a quadratic model which is further optimized using the desirability analysis $[9,10,11,12]$. The polynomial equation developed using RSM can be used to plot the three dimensional surface plots for studying the effects of design parameters on the responses $[13,14,15]$. The grey relational grade is used as the performance index in grey theory which can be further optimized by using the technique of PCA $[16,17,18]$. The desirability analysis based on Taguchi's method of experimentation is an economical technique to identify the near optimal setting of design parameters [19].

From the literature review, it is understood that GRA is an affective methodology for multi response optimization. Further limited work is addressed in the area of parameter design for epoxy based composites. Hence an attempt has been made to identify the optimal setting of design parameters for epoxy/E-glass composite using the GRA.

\section{EXPERIMENTATION}

The epoxy is chosen as the material for matrix due to better adhesion with a variety of fibres, good mechanical properties and performance at elevated temperatures. HY-951 is used as the hardener. The chopped mat (random oriented) E-glass fibres having an 
elastic modulus of $70 \mathrm{GPa}$, is used as the reinforcement. The economical and relatively less brittle glass fibres are immersed in 50 grams of $\mathrm{NaOH}$ sodium hydroxide per litre of distilled water. The treatment is carried out for an hour and the fibres are dried to improve its bond strength with the matrix. Flyash (an industrial waste), alumina and silica are chosen as particulate fillers for additional reinforcement. Based on literature, three design parameters are chosen for experimentation. The parameters are varied at three levels as shown in Table 1.

Table 1. Design parameters and their levels

\begin{tabular}{|c|c|c|c|c|}
\hline Symbols & $\begin{array}{c}\text { Design } \\
\text { parameter }\end{array}$ & $\begin{array}{c}\text { Level } \\
\mathbf{1}\end{array}$ & $\begin{array}{c}\text { Level } \\
\mathbf{2}\end{array}$ & $\begin{array}{c}\text { Level } \\
\mathbf{3}\end{array}$ \\
\hline A & $\begin{array}{c}\text { Type of } \\
\text { filler }\end{array}$ & Alumina & Silica & Flyash \\
\hline B & $\begin{array}{c}\% \text { of filler } \\
\text { (weight) }\end{array}$ & 2 & 4 & 6 \\
\hline C & $\begin{array}{c}\text { Curing } \\
\text { temperature }\end{array}$ & 30 & 60 & 90 \\
\hline
\end{tabular}

The fabricated epoxy/E-glass composite material is cut by using a hack saw and the specimen for tension test is prepared as per ASTM D638 standard. The sample for impact test (un-notched, Charpy) is also prepared in transverse direction as per ASTM D256 standard. The impact strength and tensile strength are measured using digital impact testing machine and universal testing machine. The specimen subjected to tension and impact test is shown in Fig. 1. Orthogonal array $\left(L_{9}\right)$ is used for the experimental trials and both the responses (two replications) observed are listed in Table 2. The total degrees of freedom (DOF) for the selected parameters is less than the DOF of $\mathrm{L}_{9} \mathrm{OA}$.

Table 1. Responses observed during the different trials

\begin{tabular}{|c|l|l|l|c|c|}
\hline \multirow{2}{*}{ Trial } & \multicolumn{3}{|c|}{ Design parameters } & \multicolumn{2}{c|}{ Responses } \\
\cline { 2 - 6 } & A & B & C & $\begin{array}{c}\text { Impact } \\
\text { strength } \\
\left(\mathrm{KJ} / \mathrm{cm}^{2}\right)\end{array}$ & $\begin{array}{c}\text { Tensile } \\
\text { strength } \\
\left(\mathrm{N} / \mathrm{mm}^{2}\right)\end{array}$ \\
\hline 1 & Alumina & 2 & 30 & 8.8 & 101.69 \\
\hline 2 & Alumina & 4 & 60 & 9.5 & 117.08 \\
\hline 3 & Alumina & 6 & 90 & 10.4 & 109.38 \\
\hline 4 & Silica & 2 & 60 & 6.9 & 106.82 \\
\hline 5 & Silica & 4 & 90 & 7.6 & 129.9 \\
\hline
\end{tabular}

\begin{tabular}{|c|c|c|c|c|c|}
\hline 6 & Silica & 6 & 30 & 6.5 & 119.64 \\
\hline 7 & Flyash & 2 & 90 & 7.8 & 111.95 \\
\hline 8 & Flyash & 4 & 30 & 6.9 & 109.38 \\
\hline 9 & Flyash & 6 & 60 & 6.4 & 124.77 \\
\hline
\end{tabular}

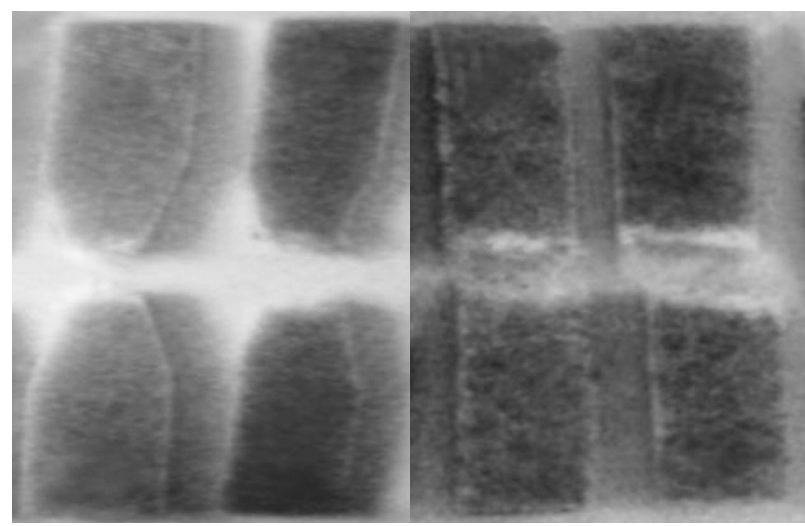

Fig. 1 Specimen subjected to tension and impact test

\section{MULTI RESPONSE OPTIMIZATION USING TAGUCHI BASED GRA}

Taguchi methods use the signal-to-noise $(\mathrm{S} / \mathrm{N})$ ratio as a measure of performance considering both mean and variance. The grey theory uses the concept of two states, one with maximum information (white) and the other with minimal information (black). The analysis of Taguchi based GRA involves the following steps resulting in the calculation of grey relational grade as the performance index.

Step 1: Calculate the $\mathrm{S} / \mathrm{N}$ ratio of the responses (larger-the-better quality characteristics) using the Eq. 1.

$$
\text { S/N Ratio }(\eta)=-10 \log \left[\begin{array}{ll}
\left.\frac{1}{n} \sum_{i=1}^{n} \frac{1}{y^{2}}\right] & 0 .
\end{array}\right.
$$

Where, $\mathrm{n}$ is the number of replications, $\mathrm{k}$ is the number of observations, $y_{i j}$ is the observed response value, $i=1,2,3 \ldots n$ and $j=1,2, \ldots k$.

Step 2: Calculate the normalized $\mathrm{S} / \mathrm{N}$ ratio values, as a part of data pre-processing using Eq. 2 . Normalization is done to reduce the range of responses and bring them on a common scale.

$$
Z_{i j}=\frac{Y_{i j}-\min \left(Y_{i j}, i=1,2, \ldots, n\right)}{\max \left(y_{i j}, i=1,2, \ldots, n\right)-\min \left(Y_{i j,}, i=1,2, \ldots, n\right)}
$$


Step 3: Calculate the grey relational coefficient (GRC) using Eq. 3. The grey relational coefficient is calculated to express the relationship between the best and actual normalized experimental results from the normalized $S / N$ ratio. The grey relational grade $(G R G)$ is calculated by taking the average of the GRC values of corresponding responses.

$$
\mathrm{V}\left(\mathrm{y}_{0}(\mathrm{k}), \mathrm{y}_{\mathrm{i}}(\mathrm{k})\right)=\frac{\Delta \min +\xi \Delta \max }{\Delta_{0 j}(k)+\xi \Delta \max }
$$

Where, $n$ is the number of Experimental data and $m$ is the number of responses.

$\Delta_{o j}=\left\|y_{o}(k)-y_{j}(k)\right\|$ is the absolute value of the difference between $\mathrm{y}_{0}(\mathrm{k})$ and $\mathrm{y}_{\mathrm{j}}(\mathrm{k})$.

$\Delta \min =\min _{\forall j \in i} \min _{\forall k}\left\|y_{0}(k)-y_{j}(k)\right\|$ is the smallest value of $y_{j}(k)$.

$\Delta \max =\max _{\forall j \in i} \max _{\forall k}\left\|y_{0}(k)-y_{j}(k)\right\|$ is the largest value of $y_{j}(k)$ and $\xi$ is the distinguishing coefficient, whose value is taken to be 0.5 to ensure an equal importance for the responses.

Step 4: Find the main effects of the parameters on the GRG values to select the optimal parameter setting.

Step 5: Perform the analysis of variance (ANOVA) to identify the contribution of various parameters in affecting the desired responses.

Step 6: Calculate the predicted $\mathrm{S} / \mathrm{N}$ ratio for the responses.

Step 7: Perform the confirmation experiment to authorize the method.

\section{RESULTS AND DISCUSSION}

\section{A. Data Pre-processing}

The data pre-processing is done to bring the quality characteristics (impact strength and tensile strength) on a common and reduced scale. The technique of Taguchi based GRA is implemented and the $\mathrm{S} / \mathrm{N}$ ratio values are calculated for the individual responses. The normalized values are listed in Table 3.

\section{B. Grey Relational Grade}

The GRC values are sorted out to present the relationship between the best and actual normalized experimental results from the normalized $\mathrm{S} / \mathrm{N}$ ratio. The GRG is calculated as the mean of the GRC values of corresponding responses. The plot of GRG values for various trials is shown in Fig. 2. The considerable variation in the GRG values for different trials signify the range and levels of different design parameters chosen for experimentation. The GRC and GRG values are listed in Table 4.

Table 3. Pre-processed data

\begin{tabular}{|c|c|c|c|c|}
\hline \multirow{2}{*}{ Trial } & \multicolumn{2}{|c|}{ S/N ratio } & \multicolumn{2}{c|}{ Normalized S/N ratio } \\
\cline { 2 - 5 } & $\begin{array}{c}\text { Impact } \\
\text { strength }\end{array}$ & $\begin{array}{c}\text { Tensile } \\
\text { strength }\end{array}$ & $\begin{array}{c}\text { Impact } \\
\text { strength }\end{array}$ & $\begin{array}{c}\text { Tensile } \\
\text { strength }\end{array}$ \\
\hline 1 & 18.890 & 40.146 & 0.656 & 0.000 \\
\hline 2 & 19.555 & 41.370 & 0.814 & 0.576 \\
\hline 3 & 20.341 & 40.779 & 1.000 & 0.298 \\
\hline 4 & 16.777 & 40.573 & 0.155 & 0.201 \\
\hline 5 & 17.616 & 42.272 & 0.354 & 1.000 \\
\hline 6 & 16.258 & 41.558 & 0.032 & 0.664 \\
\hline 7 & 17.842 & 40.981 & 0.408 & 0.393 \\
\hline 8 & 16.777 & 40.779 & 0.155 & 0.298 \\
\hline 9 & 16.124 & 41.922 & 0.000 & 0.835 \\
\hline
\end{tabular}

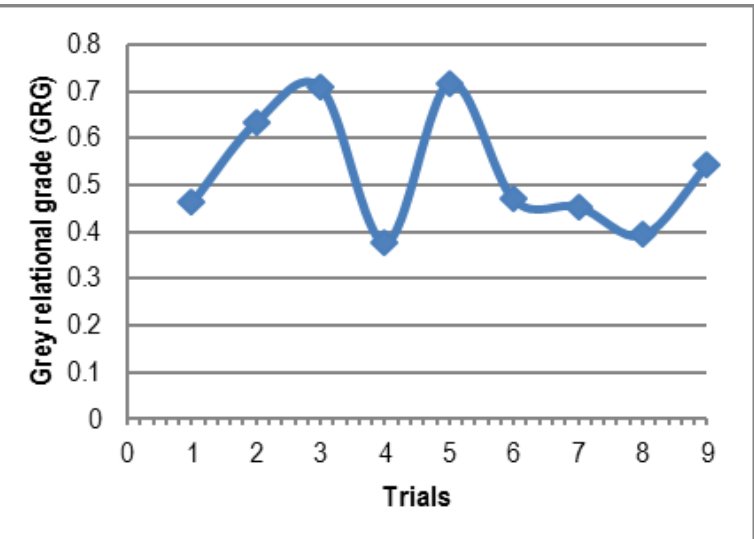

Fig. 2 Plot of GRG values for different trials

Table 4. GRG values

\begin{tabular}{|c|c|c|c|}
\hline \multirow{2}{*}{ Trial } & \multicolumn{2}{|c|}{ GRC values } & \multirow{2}{*}{ GRG values } \\
\cline { 2 - 3 } & $\begin{array}{c}\text { Impact } \\
\text { strength }\end{array}$ & $\begin{array}{c}\text { Tensile } \\
\text { strength }\end{array}$ & \\
\hline 1 & 0.5924 & 0.3333 & 0.4628 \\
\hline 2 & 0.7284 & 0.5409 & 0.6346 \\
\hline 3 & 1.0000 & 0.4159 & 0.7079 \\
\hline 4 & 0.3717 & 0.3849 & 0.3783 \\
\hline 5 & 0.4363 & 1.0000 & 0.7181 \\
\hline 6 & 0.3406 & 0.5980 & 0.4693 \\
\hline 7 & 0.4576 & 0.4515 & 0.4546 \\
\hline 8 & 0.3717 & 0.4159 & 0.3938 \\
\hline 9 & 0.3333 & 0.7524 & 0.5428 \\
\hline
\end{tabular}




\section{Selection of Optimal Parameters and ANOVA}

The main effect of each design parameter on GRG is calculated for each level and shown in Table 5. The best level of each factor is identified as the one with the maximum value of GRG. The maximum value of GRG is desired irrespective of the nature of quality characteristics. The optimal parameter level was found out as $A_{1} B_{2} C_{3}$. The result of ANOVA on GRG is shown in Table 6 . The ANOVA table can be used to categorize the contribution of the various process parameters in affecting the responses. The contribution chart shown in Fig. 3 gives the contribution of each parameter in affecting the responses.

Table 5. Main effect of parameters on GRG

\begin{tabular}{|c|c|c|c|c|}
\hline Parameters & $\begin{array}{c}\text { Level } \\
\mathbf{1}\end{array}$ & $\begin{array}{c}\text { Level } \\
\mathbf{2}\end{array}$ & $\begin{array}{c}\text { Level } \\
\mathbf{3}\end{array}$ & $\begin{array}{c}\text { Max- } \\
\text { Min }\end{array}$ \\
\hline A & 0.6018 & 0.5219 & 0.4637 & 0.1381 \\
\hline B & 0.4319 & 0.5822 & 0.5734 & 0.1503 \\
\hline C & 0.4420 & 0.5186 & 0.6269 & 0.1849 \\
\hline
\end{tabular}

\section{Confirmation Experiment}

After obtaining the optimal level of the design parameters using the approach of Taguchi based GRA, the confirmation test is conducted to verify the improvement in the performance characteristics. The results of the confirmation experiment conducted with the optimal parameter setting are compared with those obtained with initial setting of parameters (Table 7). A significant change in the response values is observed with the optimal design parameters.

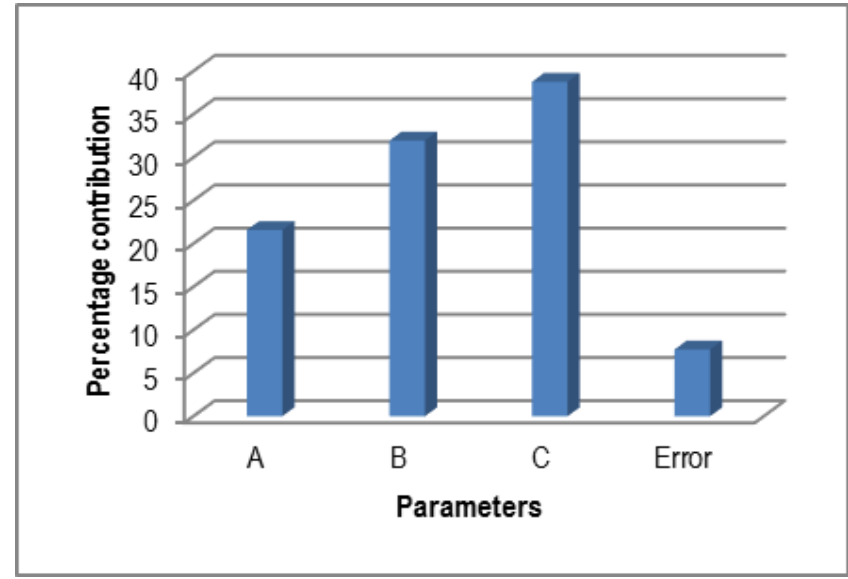

Fig. 3 Influence chart

Table 6. Result of ANOVA on GRG

\begin{tabular}{|c|c|c|c|c|c|}
\hline $\begin{array}{c}\text { Source } \\
\text { of } \\
\text { variance }\end{array}$ & $\begin{array}{c}\text { Sum of } \\
\text { squares }\end{array}$ & DOF & $\begin{array}{c}\text { Mean } \\
\text { sum } \\
\text { of } \\
\text { square }\end{array}$ & $\begin{array}{c}\text { F- } \\
\text { ratio }\end{array}$ & $\begin{array}{c}\% \\
\text { Contribution }\end{array}$ \\
\hline A & 0.0288 & 2 & 0.0144 & 2.7929 & 21.58 \\
\hline B & 0.0427 & 2 & 0.0213 & 4.1340 & 31.94 \\
\hline C & 0.0518 & 2 & 0.0259 & 5.0165 & 38.76 \\
\hline Error & 0.0103 & 2 & 0.0052 & & 7.72 \\
\hline Total & 0.1336 & 8 & & & 100 \\
\hline
\end{tabular}

Table 7. Comparison between the outcome of initial parameter setting and optimal parameter setting

\begin{tabular}{|c|c|c|c|c|c|c|}
\hline \multirow{2}{*}{ Responses } & \multicolumn{2}{|c|}{$\begin{array}{c}\text { Initial parameter } \\
\text { Setting }\end{array}$} & \multicolumn{2}{c|}{$\begin{array}{c}\text { Optimal parameter } \\
\text { setting } \\
\text { using GRA }\end{array}$} & \multicolumn{2}{c|}{ Improvement } \\
\cline { 2 - 7 } & $\begin{array}{c}\text { Predicted } \\
\text { S/N ratio }\end{array}$ & $\begin{array}{c}\text { Response } \\
\text { value }\end{array}$ & $\begin{array}{c}\text { Predicted } \\
\text { S/N ratio }\end{array}$ & $\begin{array}{c}\text { Response } \\
\text { Value }\end{array}$ & $\begin{array}{c}\text { S/N } \\
\text { ratio }\end{array}$ & $\begin{array}{c}\text { Response } \\
\text { value }\end{array}$ \\
\hline $\begin{array}{c}\text { Charpy } \\
\text { impact }\end{array}$ & 20.1734 & 10.24 & 20.5818 & 10.83 & 0.4084 & 0.59 \\
\hline $\begin{array}{c}\text { Tensile } \\
\text { strength }\end{array}$ & 41.2217 & 110.15 & 41.2757 & 124.46 & 0.0540 & 14.31 \\
\hline $\begin{array}{c}\text { Parameter } \\
\text { settings }\end{array}$ & \multicolumn{2}{|c|}{$\mathrm{A}_{1} \mathrm{~B}_{3} \mathrm{C}_{3}$} & \multicolumn{2}{|c|}{$\mathrm{A}_{1} \mathrm{~B}_{2} \mathrm{C}_{3}$} & & \\
\hline
\end{tabular}




\section{CONCLUSION}

This paper has disclosed the application of Taguchi based GRA to identify the optimal design parameters for epoxy/E-glass composite. The following conclusions can be drawn. The uncertainty handling capabilities of Taguchi based GRA is employed to predict the optimal design parameters for epoxy/E-glass composite as filler material- alumina, $\%$ weight of filler- 4 and curing temperature- $90^{\circ} \mathrm{C}$.

-The ANOVA results have shown that curing temperature is the primary parameter influencing the responses with a contribution of $38.76 \%$.

-The confirmation test has validated the application of Taguchi based GRA in selecting the best design parameters.

\section{REFERENCES}

[1] Chang. S.H., Hwang. J.R., Doong. J.L., 2000, Optimization of the injection molding process of short glass fiber reinforced polycarbonate composites using grey relational analysis, Journal of Materials Processing Technology, 97 (1-3), pp. 186193.

[2] Karthikeyan. R., Adalarasan. R., Pai. B.C., 2002, Optimization of Machining Characteristics for Al/SiCp Composites using ANN/GA, Journal of Material Science and technology, 18 (1), pp. 47-50.

[3] Adalarasan. R., Santhanakumar. M., 2015, Application of Taguchi based Response Surface Method (TRSM) for Optimization of Multi Responses in Drilling $\mathrm{Al} / \mathrm{SiC} / \mathrm{Al}_{2} \mathrm{O}_{3}$ Hybrid Composite, Journal of the Institution of Engineers (India): Series C, 96 (1), pp. 65-71.

[4] Adalarasan. R., Santhanakumar. M., 2015, Parameter Design in Fusion Welding of AA 6061 Aluminium Alloy Using Desirability Grey Relational Analysis (DGRA) Method, Journal of the Institution of Engineers (India): Series C, 96(1), pp. 5763.

[5] Adalarasan. R., Santhanakumar. M., Shanmugasundaram. A., 2014, Optimization of Friction Welding Parameters for AA6061T6/AA2024-T6 Joints Using Taguchi-Simulated Annealing (TSA) Algorithm, Applied Mechanics and Materials, 592-594, pp. 595-599

[6] Santhanakumar. M., Adalarasan. R., Rajmohan. M., 2015, Parameter design in plasma arc cutting of galvanised iron sheet using desirability function based response surface methodology (DRSM), International Journal of Manufacturing Research, 10 (3), pp. 199-214.

[7] Adalarasan. R., Santhanakumar, M., 2014, Study on Friction Welding of Aluminium based Composites using Desirability Analysis, International Journal on Design \& Manufacturing Technologies, 8(1), pp.1-4.
[8] Santhanakumar. M., Adalarasan. R., 2014, Study of Compression Molding of GFRP using Grey Relational Analysis, International Journal on Design \& Manufacturing Technologies, 8 (1), pp. 36-39.

[9] Adalarasan. R., Santhanakumar. M., Rajmohan. M., 2015, Application of Grey Taguchi-based response surface methodology (GT-RSM) for optimizing the plasma arc cutting parameters of 304L stainless steel, International Journal of Advanced Manufacturing Technology, 78 (1), pp. 1161-1170.

[10] Santhanakumar. M., Adalarasan. R., Rajmohan. M., 2015, Experimental Modelling and Analysis in Abrasive Waterjet Cutting of Ceramic Tiles Using Grey-Based Response Surface Methodology, Arabian Journal for Science and Engineering, 40 (11), pp. 3299-3311.

[11] Adalarasan. R., Santhanakumar. M., Thileepan. S., 2015, Investigation on strength of solid state $\mathrm{Al} 6061 / 30 \% \mathrm{Al}_{2} \mathrm{O}_{3}$ bonds for automotive applications using response surface methodology (RSM), International Journal of Automotive Composites, 1 (4), pp. 364-374.

[12] Adalarasan. R., Santhanakumar. M., Rajmohan. M., 2014 , Application of desirability analysis for optimizing the micro wire electrical discharge machining ( $\mu$ WEDM) parameters, Applied Mechanics and Materials, 592-594, pp. 77-81.

[13] Santhanakumar. M., Adalarasan. R., 2014, Application of Grey Taguchi based Response Surface Methodology (GT-RSM) in Injection Moulding of Polypropylene/E-glass Composite, International Journal of Manufacturing, Materials, and Mechanical Engineering, 5 (1), pp. 35-48.

[14] Adalarasan. R., Santhanakumar. M., Rajmohan. M., 2015, Optimization of laser cutting parameters for Al6061/SiCp/Al2O3 composite using grey based response surface methodology (GRSM), Measurement, 73, pp. 596-606.

[15] Adalarasan. R., Santhanakumar. M., 2015, Response surface methodology and desirability analysis for optimizing $\mu$-WEDM parameters for $\mathrm{Al} 6351 / 20 \% \mathrm{Al}_{2} \mathrm{O}_{3}$ composite, International Journal of ChemTech Research, 7 (6), pp. 2625-2631.

[16] Adalarasan. R., Shanmuga Sundaram, A., 2015, Parameter design and analysis in continuous drive friction welding of Al6061/SiCp composites, Journal of Mechanical Science and Technology, 29 (2), pp. 769-776.

[17] Adalarasan. R., Santhanakumar. M., Shanmugasundaram, A., 2014, Optimization of weld characteristics of friction welded AA 6061-AA 6351 joints using grey-principal component analysis (G-PCA), Journal of Mechanical Science and Technology, 28 (1), pp. 301-307.

[18] Adalarasan. R., Shanmuga Sundaram. A., 2015, Parameter design in friction welding of $\mathrm{Al} / \mathrm{SiC} / \mathrm{Al} 2 \mathrm{O} 3$ composite using grey theory based principal component analysis (GT-PCA), Journal of the Brazilian Society of Mechanical Sciences Engineering, 37 (5), pp. 1515-1528.

[19] Atul. S.C., Adalarasan. R., Santhanakumar. M., 2015, Study on Slurry Paste Boronizing of 410 Martensitic Stainless Steel Using Taguchi Based Desirability Analysis (TDA), International Journal of Manufacturing, Materials, and Mechanical Engineering, 5 (3), pp. 64-77. 